Journal of English Teaching Adi Buana, Vol. 03 No. 01, April 2018

\title{
THE EFECTIVENES OF USING COMIC IN TEACHING READING NARRATIVE TEXT
}

\author{
Farid Helmi Setyawan \\ STKIP Modern Ngawi \\ faridhelmi@stkipmodernngawi.ac.id
}

\begin{abstract}
This study is focused on using comic as media in teaching reading at eight grade student of Junior High School in Ngawi. The problem in this study was the students' motivation on reading especially on narrative text was low and their score in some test was average low. They still confused to understand the content of the story, it was proved by the score on their test was average low in reading questions, it was 65,7 and they could not retell the content of the story briefly. By using the comic in teaching learning, the students are helped to understand the contents of the story that they read. The method in this study used qualitative research in the term of case study. The subject of the study was eight grade students of junior high school. The number of participant was 60 students. The result of the study showed that the implementation of teaching reading by using comic as media give benefit to students, it showed from 48 of 60 students or $80 \%$ of the students agreed the use of comic as learning media. From the questionnaire result, the comic gives benefit in teaching reading to the students' reading skills improvement. It revealed that 52 of 60 students or $87 \%$ of the students positively responded after the implementation activities yet only $13 \%$ of the students showed their uncertainty of its benefits. The use of comic can also be combined by other techniques in order to develop the understanding of material and make the students enjoy, interest, and enthusiasm during teaching learning process. Moreover, the result showed that comic helped students in understanding the content of the story.
\end{abstract}

Keywords: teaching reading, comics, narrative text

\section{TRODUCTION}

Reading, as one of language skills, has a very important role. The students should comprehend the reading for certain purpose however it needs a practical and suitable method. The idea is supported by the fact that reading now has a part of daily life. Reading cannot be separated from daily activities. Students read many kinds written materials such as newspapers, magazines, novels, academic books and so on. Through reading students can get a lot of information, knowledge, enjoyment and even problem solution. Reading can be seen as an interactive process between a reader and a text which leads to automatically or reading fluency (Alyousef, 2005). Nunan (2003) states that reading is an essential skill for students of English as a foreign language. For most of these students it is 
the most important skill to master in order to ensure success not only in learning English, but also in learning in any content class where reading English is required. By strengthening English reading skill, students will make great progress and development in all other areas of learning. Reading is useful for language acquisition. Students also got more positive effect from reading. By reading they got vocabularies knowledge, on their spelling and writing.

According to Beckman \& Diamond (1984) Students who are reading in the bellow grade level do not have to exhaust themselves trying to comprehend a comic text, which enable them to relax, a stance that certainly facilitates learning. Since English is a foreign language, it is understandable that most students face difficulties in understanding a piece of reading text. These difficulties sometimes make students frustrated. They lose their motivation to learn English so they do not enjoy learning English. English as foreign language is considered difficult to learn especially in reading because English is not the mother of tongue of the students.

Harmer (2008) states the aim of all committed teachers is to facilitate learning. It really needs creative efforts from the English teacher to conduct the process of teaching-learning. To be more interesting the teacher have to create many ways to explain the subject so that it can be understood well by the students.

One of things that English teacher face is the difficulties to teach English as foreign language because of limited time, limited media, limited source and how to encourage students to find their interesting and enjoy to learn English especially reading.

Fuadi (2008) explains that it is very important that teacher should choose and select reading material and media. Teacher must consider students' competence as well as curriculum, because curriculum is the standard competence in teaching learning at school. If the teachers have found right materials, they must select good media too, because good media will support teaching learning process. Setyowati (2009) states, there are three kinds of media as we know. They are audio, visual, and audio visual media. Media that we can listen is audio, and the media that we can see is visual, while, the media that we can listen and see is named audio visual. As a teacher, it is important to decide the right media when taught the students.

Comic is series of adjacent drawn images, usually arranged horizontally, that are designed to be read as a narrative or a chronological sequence (Encyclopedia Britannica). A comic can be defined as "a series of pictures inside boxes that tell a story" (Liu, 2004). According to McCloud (2008), comic is a literature of drawings. Comic are a composition or other images in purposeful sequence and they have an aim to convey information and visual response in the view. According to Mallia (as cited in Beard and Rhodes, 2002), comic is a narrative text told by way of sequences of pictures which has continue cast from one sequence to the next and the enclosure of dialogue and/or text within the pictures. The vocabulary is the whole visual symbols. Kane (2007) states that the use of comics can gain the readers' trust, begin the process of building their confidence and offer successful reading experience.

In this study, the purpose of the study was to analyze the process of teaching reading by using comics on the junior high school students' engagement these texts. In this study, the researcher tried to find out the best media which 
hopefully can improve or increase students' reading comprehension especially in narrative text.

The problem underlying this study was the students' motivation in reading and their understanding on the content of the story was low, it showed from the interview with some students that they felt bore with reading passage. In the other case, the students' score was low with the average score was 65,7 .

The focus of the study was on students' reading comprehension especially on understanding detailed information of the text. Based on the problems, the researcher offered comic book to solve the problems. By combined with other strategy, the researcher used comic to help the students in understanding the content of the story. The aim of this research was to know how comic can be improved students' reading ability especially on their understanding of story content and improved students' motivation on reading.

The use of suitable media is hoped can help teacher to create meaningful instructions and also motivate students to improve their reading. The media which is appropriate for the research's goal is comic. It is because many people, especially students love comics. Most of children and young even adults love comics because of their visual, attractive, humorous, and overall appeal (Hillman, 1995).

A second reason, comic is interesting media which provide pictures and dialogues. The dialogues and the pictures in Comic can make it easier for the students to find the idea about what they are going to write. Comic Strips are also good media. Using Comic can avoid students' boredom because of the attractive appearance.

\section{METHOD}

The research method is qualitative. Bodgan and Tylor (1998) defined the qualitative approach as a research procedure which produces a descriptive data such as verbal or non verbal utterances or words from the object being observed. Stake (2010) states that qualitative approach presents the information concerning the current status of phenomenon and it is directed toward determine of situation as it exist at the time of the study. Although essentially all qualitative analysis is content based, content analysis was particularly applicable for this case study, for the interviews, observations, and documents revealed patterns and themes closely connected to the research questions Merriam (1998). The analysis methodology simply involved coding the raw data and then creating appropriate categories based on the emerging ideas. Because I approached the case study with a general hypothesis in mind and ready to be tested, I limited category construction to only those themes directly connected to comic use in the classroom. Although related contexts also emerged, (i.e., use of technology and assessment types), I eliminated those areas of study as there was plenty of directly applicable data to mine.

\section{Research Subject and Setting}

The research subject is the English teacher and 60 students of grade eight. The setting of the research is in Junior High School. 


\section{Source of Data}

The data source of this research is taken from the teaching learning activity in the classroom when the students got reading section in narrative text in the chapter of understanding main idea.

\section{Data Collection Technique}

The data collection of this study is using interview, observation, and questionnaires. The most basic method of data collection of this study is observation for obtaining the data sources. To support the study, the researcher also using supporting instrument to collect the data, they are form of observation sheet, interview and questionnaire. The observation sheet is used to collect data which related to the process of teaching learning in the classroom. The interview is used for a number of purposes, they are: (1) Knowing unique information that not happened in the classroom activity, (2) Collecting many information from many persons, (3) Finding about things that researcher cannot observe. The questionnaire is used to obtain the data about students' attitude on the implementation of active learning. It consists of ten number and given to the students after teaching learning process.

\section{Data Analysis}

Data analysis is a system to arrange the data and present to other. Miles and Huberman (1994) view that qualitative data analysis consists of data reduction, data display, and drawing conclusion.

Data reduction is the stage of processing the "raw" data in order to be ready to be analyzed. The process form of data analysis are selecting, simplifying, focusing, summarizing, coding, sorting, or even making cluster of the themes.

Data display is the process of demonstrating the data either in the form of narrative text, matrices, graphs, network or charts. In the context of this research, the data were displayed in the form of conversational excerpts, classroom interaction and result of interview.

Both of the steps above, starting from reducing data to displaying data, are applied each time the researcher obtained data from one topic session. Based on these activities, the researcher make conclusion of the analysis and focused the attention in the subsequent data collection. The conclusion is written based on the analysis of the observation sheet, result of the interview, and documentation in the relation to the research by calculating and summarizing the data.

\section{FINDINGS AND DISCUSSION}

The issue of using comic in the teaching learning process is how it connected to its usefulness. Pertinent to the real practice in teaching learning, the effectiveness of using comic is indicated by Ahmad Kurniadi (2012), Purwanitasari (2010) and Lutfifati (2011). They conducted their research to the same education level but different aspects and genre of the text. Ahmad Kurniadi conducted his research on reading comprehension, but Purwanitasari and Lutfifati conducted their research on writing. Ahmad Kurniadi's findings showed that the implementation of comic book could improve the students' narrative text reading 
comprehension of the eight grade students of SMPN 8 Bandar Lampung. Purwanitasari's findings showed that comic strips successfully improved the ability of the eighth graders of SMPN 2 Malang in writing recount texts. Meanwhile, Lutfifati's findings supported Purwanitasari's research by giving evidence that comic strip is a good strategy to solve writing problems faced by the eighth graders of SMPN 9 Malang, particularly in writing narrative texts.

The first question I wanted to address via the case studies was: how is student engagement impacted by the supplemental use of comic in upper level classrooms? What I discovered was that student engagement was clearly the most impacted area of interest in the entire study. They were helped in understanding the content of the story. Even they did not know the meaning of the sentences, by seen the picture on the comic, they could guess what the story talking about. The level of student engagement dramatically increased in every class during the time the comic were read and discussed, and in some cases, the heightened student engagement continued throughout the unit and beyond its conclusion. The students are more enthusiasm in reading process. They focused on the teaching learning process. The students said that they were happy with the teaching learning using comic. The teachers and interns were unified and unequivocal in their belief that student engagement was positively affected by comic use, and they all elicited surprise at the obvious impact on their students. When the students first realized they were going to hear and see a comic, their initial reactions were mixed. Because of the age question (addressed earlier), some students groaned, rolled their eyes, or made statements such as, "You are seriously not going to read us a kids' book!" Others less concerned with selfimage responded physically and verbally, displaying such behaviors such as hand clapping and child like exclamations of happiness. Most, however, were simply quiet and revealed mild curiosity through attention to the activity. But after the teacher explains the new method, they can understand and accepted it. Before using comic as media, they usually got boring when the teacher asked them to read some reading passage, but after the teacher used the comic, they began to interest.

At the teaching learning process, because the first time they are taught by comic as media, some students still enjoyed with themselves. They did not have more attention to the learning activity. The teacher then combined the media with cooperative learning strategy so the students began to interest.

There was a problem during teaching learning process. The teacher was difficult to find the suitable material which match with the curriculum. But the problem could be solved by browsing some materials on the internet.

At the result addition, teaching learning used comic media, the students felt that they are challenged by the material. The students felt curious with the story and the meaning of the sentences in each pictures, so they tried to find the meaning on the dictionary. By finding the meaning of the sentences in the dictionary, it made the students improve their vocabularies. So, their ability on understanding detail information of the text improved.

During post-case study interview, the teachers and interns expressed some concern about the comic creating a sense of fun in the classroom, but the students had no such reservations. They often said they enjoyed hearing and seeing the books, and a great deal of laughter accompanied the lessons, including from the 
teachers. Another theme that arose was students' automatic suspicion of and negative reaction to perceived "work." I often noticed students delay getting started on an assignment or asking for assistance on a task before exerting initial attempts. These are aspects of work avoidance or work resistance, and they are common in high school classrooms.

Finally, I wanted to understand whether the use of comic impacted the students' mastery of the material. In other words, were the learning goals of the teachers achieved? Although not as obvious as the clear link to engagement, student learning was impacted, especially among the ELLs and those students who are less likely to be successful at reading tasks. As I evaluated the data, I noticed that learning gains clustered around skill acquisition and connecting to prior knowledge. Perhaps just as significantly, though, the comic dramatically stimulated students' verbal response, both in quantity and quality.

The conclussion, comic in teaching reading could provide language input such as vocabulary and functional expressions. It was found that 48 of 60 students or $80 \%$ of the students agreed the use of comic as learning media. The comic help the students understand the material and improve their reading skill particularly. From the questionnaire result, the comic gives benefit in teaching reading to the students' reading skills improvement. It revealed that 52 of 60 students or $87 \%$ of the students positively responded after the implementation activities yet only $13 \%$ of the students showed their uncertainty of its benefits.

\section{Discussion of How the Teacher Implement Comics in the Teaching Reading at Eighth Grade Students of Junior High School in Ngawi.}

Based on the finding of this research, it proved that the use of comic as media in teaching reading at Junior High School is one of appropriate to teach narrative text and give beneficial contribution in improving students' ability in reading. Bringing a new instructional methodology to the classroom stimulates teacher reflection about their practices which inevitably improves the classroom culture and situates the teacher alongside the students in a learning role. Sharing comic with students is no exception. The following list describes some of the awareness the teachers noticed of themselves during the case studies:

a. A need for improved student rapport,

b. A desire to investigate students' early reading experiences, whether positive or negative,

c. The criticality of scaffolding learning,

d. Motivation to try new instructional methods,

e. Guilt and self-criticism when lessons are not effective, if even for only one student,

f. The importance of reflective teaching,

g. Bringing creativity to the classroom,

h. The need to be sensitive to students' individual learning styles,

i. The necessity of frequently using advanced organizers,

j. The importance of direct, explicit instruction,

$\mathrm{k}$. An awareness of the complexity of the teenage experience.

This media was implemented as process of comprehending text and as constructing meaning from written text. For EFL learners, reading comprehension is primarily things. By reading, the students try to understand the meaning of 
words or sentence. In this case need strategy to make the students interesting on reading. Using comic is one of strategy to make students interesting on reading. Comic help the students to decoding and visualization the information and give illustration to the students when they read. Comic helped the students understand the content of the story, even they didn't

There are so many components that support teaching learning process. Those components often used by the teacher to present an innovative teaching. Teacher must prepare the materials before they teach. The materials that must be drawn up before teaching reading are (1) lesson plan, (2) reading material, (3) instructional media, (4) Assessment form. Besides, the teacher used comic media, the teacher also combined with cooperative learning strategy. This way was taken in order the students could be arranged as the teacher's plan. The strategy was match with the comic media.

\section{Discussion of What Kinds of Problems Arises during the Implementation at Eighth Grade Students of Junior High School in Ngawi.}

Based on the finding of this research by interviewing the teacher it is proved that the use of comic media in teaching reading has some problems which arise during the implementation. The data of interview show that it takes much more time to prepare the learning stuff before the time begins. For instance, the teacher must prepare and find story or comic that match with the topic. But it could be solved by browsing the materials on the internet. The next problem is the inadequate time. The teacher has to manage the time in such a way to explain the material. But the problem could be solved by combined the material with cooperative learning strategy.

\section{Discussion of What Students' Responses Are Toward the Implementation at Eighth Grade Students of Junior High School in Ngawi.}

Based on the finding of this research by giving questionnaires to the students, it proved that the used of comics media in teaching reading has positive responses. Almost all of the students felt very enthusiastic to read the text, strongly motivated to read, and felt confident in answering the question in reading. Even though, at the first time of the implementation, they felt that they like a kids. The study revealed that weak readers' prior knowledge helped and motivated the readers if they were familiar with the stories in their mother of tongue prior to reading the stories in a second language.

\section{CONCLUSION}

After the researcher held the research, he inferred the implementation of comic in teaching reading on junior high school students at Junior High School in Ngawi. With the research findings and discussion, the researcher offers some suggestions. The suggestions are addressed to the teacher and future researchers. The teachers who have the same problems with the teacher in Junior High School in Ngawi are suggested to employ the comic as media to make the students feel enthusiastic and active in process of reading. The teachers should focus on preparing lesson plans and selected the appropriate material which suitable with 
the students level. The important things that the teacher should do are that they have to combine the material with cooperative learning strategy.

Future researchers, particularly those who are interested in applying comic as media in their research are suggested that they conduct a research in the teaching of reading narrative text in different level. Moreover, it is also suggested that future researchers conduct action research in the teaching reading using different genre.

\section{REFERENCES}

Apriani, N. (2009). Teaching reading using storybook reading at SD 1 Trosemi Gatak. (Unpublished Thesis). Surakarta: Muhammadiyah University of Surakarta.

Ary, D., Jacobs. L. C., Razavieh. A., \& Sorensen, C. (2010). Introduction to research in education. Belmont: Thomson.

Beckman, J., \& Diamond, J. (1984). Comic in the Classroom: The Secret Weapon for the Creative Teacher. TheEnglish Journal, 73. 102-104.

Brown, H. D. (2007). Teaching by principle: An interactive approach to language pedagogy. New York: Pearson Education.

Bogdan, R., \& Tylor, S.J. (1998). Introduction to Qualitative Research Methods: A Guidebook and Resource, 4th Edition. Wiley

Fuadi, A.H. (2008). Frequency of Reading English Materials and Listening Achievement. Undergraduate Paper of UPI Bandung. UPI Bandung: Unpublished.

Harmer, J. (2007). How to teach English. Essex: Pearson Longman.

Harmer, J. (2008). The practice of English language teaching. Essex: Pearson Longman.

Hillman, J. 1995. Discovering Children's Literature. Englewood Cliffs, NJ: Prentice Hall.

Kane, S. (2007). Literacy \& learning in the content areas, second edition. Scottsdale, Holcomb Hathaway.

Kurniadi, A. (2012). Teaching Reading Comprehension Narrative Text Through Comic Book at Second Grade of SMPN 8 Bandar Lampung. (Unpublished Skripsi). Bandar Lampung. Universitas Bandar Lampung.

Lutfifati, N.I. (2011). Using Comic Strips to Improve Eighth Grade Students' Ability in Writing Narrative Texts at SMP N 9 Malang. Unpublished Undergraduate Thesis. Malang: State University of Malang.

McCloud, S. 2008. Reinventing Comics. Jakarta: Kepustakaan Populer Gramedia.

Miles, M. \& M.H. (1994). Qualitative data analysis: An expanded sourcebook. Baverly Hills: SAGE Publication Inc.

Nunan, D. (2003). Practical English language teaching. Singapore: McGraw-Hill Education.

Purwanitasari, L. (2010). Using Comic Strips to Improve the Ability of Students of SMP Negeri 2 Malang in Writing Recount Text. (Unpublished Undergraduate Thesis). Malang: State University of Malang.

Setyowati, A. (2009). Upaya Meningkatkan Kecerdasan Verbal Linguistik Anak Melalui Membaca. Surakarta: UMS. 
Journal of English Teaching Adi Buana, Vol. 03 No. 01, April 2018

Stake, R. E. (2010). Qualitative Research: Studying How Things Work. New York, NY: Guilford Press. 244 pages 